\section{JURNAL EKONOMI EFEKTIF}

ISSN : $2622-8882$, E-ISSN : 2622-9935

Jurnal Ekonomi Efektif, Vol. 3, No. 2, Januari 2021 @Prodi Manajemen Fakultas Ekonomi Universitas Pamulang

\title{
PENGARUH KOMPENSASI, KOMPETENSI DAN MOTIVASI TERHADAP KINERJA KARYAWAN UNIVERSITAS PAMULANG
}

\author{
Putra Perdamean Nauli \\ Universitas Pamulang, Tangerang Selatan, Banten, Indonesia \\ dosen02562@unpam.ac.id
}

Manuskrip: Sept-2020; Ditinjau: Okt-2020; Diterima: Nov-2020; Online: Jan-2021; Diterbitkan: Jan-2021

\begin{abstract}
ABSTRAK
Penelitian ini bertujuan untuk menguji kompensasi. kompetensi dan Motivasi, memiliki pengaruh terhadap Kinerja karyawan, Responden penelitian terdiri para karyawan pada Universitas Pamulang Tangerang selatan. Populasi dan sample sebanyak120 responden. Menggunakan teknik sample jenuh. Peneliatan ini menggunakan metode Kuantitatif dan Pengolahan data menggunakan pengujian validitas, pengujian reliabilitas, uji asumsi klasik, uji regresi linier dan uji korelasi melalui program Statistical Package for The Social Science (SPSS) versi 22.0. Hasil penelitian menyatakan bahwa kompensasi, kompetensi dan motivasi berpengaruh positif dan signifikan terhadap kinerja karyawan. Dan besarnya pengaruh dari varibel kompensasi, kompetensi dan motivasi terhadap kinerja karyawan adalah 14,7\% tergolong kategori setuju, sedangkan sisanya 85,3\% tergolong kategori tidak setuju dalam penelitian ini.
\end{abstract}

Kata Kunci: Kompensasi, Kompetensi,, Motivasi, dan Kinerja.

\begin{abstract}
This study aims to test compensation. competence and motivation, have an influence on employee performance. Respondents of the study consisted of employees at Pamulang University, South Tangerang. Population and sample of 120 respondents. Using saturated sample technique. This research uses quantitative methods and data processing uses validity testing, reliability testing, classical assumption tests, linear regression tests and correlation tests through the Statistical Package for The Social Science (SPSS) program version 22.0. The results compensation, competence and motivation have a positive and significant effect on employee performance. And the magnitude of the influence of the compensation, competence and motivation variables on employee performance is $14.7 \%$ classified as agree, while the remaining $85.3 \%$ are classified as disagree in this study.
\end{abstract}

Keywords: Compensation, Competence, Motivation, and Performance. 


\section{PENDAHULUAN}

\section{A. Latar Belakang Masalah}

Universitas Pamulang (UNPAM) merupakan Universitas Swasta yang berada di daerah Pamulang Tangerang Selatan, Provinsi Banten Indonesia. Perkembangan Universitas Pamulang sangat pesat sejak tahun 2006 hingga sekarang. Ini ditunjukkan dengan adanya 3 (tiga) lokasi Universitas Pamulang yaitu: Unpam Pusat, Witana dan Viktor. Ketiga lokasi Universitas pamulang ini telah beroperasi. Peminat Universitas Pamulang tidak kalah dengan Universitas lainnya, malah lebih tinggi peminat pada Universitas Pamulang ini. Dengan banyaknya peminat Universitas Pamulang, maka diperlukan banyak karyawan yang berkompeten untuk menjalankan Universitas (instansi) ini. Setiap instansi tentu ingin mendapatkan hasil yang maksimal atau dengan kata lain ingin mendapatkan keuntungan dari kegiatan usaha tersebut, begitupun dengan Universitas Pamulang.

Sumber daya manusia pada sebuah instansi (UNPAM) perlu dikelola secara profesional agar terwujud keseimbangan antara kebutuhan karyawan dengan tuntutan dan kemampuan instansi. Tidak wajar jika banyak karyawan yang sebenarnya secara potensi berkemampuan tinggi tetapi tidak mampu berprestasi dalam bekerja, hal ini dimungkinkan karena ada faktor lain yang mempengaruhinya. Sangat disayangkan, sebuah instansi yang mempunyai tenaga kerja berpotensi tinggi tetapi tidak mampu bekerja secara produktif.

Pencapaian kinerja sesuai yang diharapkan instansi (perusahaan) dari seorang karyawan tidak mudah karena dipengaruhi oleh berbagai faktor. Suatu instansi harus mampu menganalisis faktor-faktor yang dapat mempengaruhi kinerja karyawan tersebut. Kinerja Karyawan merupakan hasil kerja yang dicapai oleh individu yang disesuaikan dengan peran atau tugas individu tersebut dalam suatu instansi dan periode tertentu, yang dihubungkan dengan suatu ukuran nilai atau standar tertentu dari instansi di mana individu tersebut bekerja.

Teknologi yang semakin berkembang merupakan sarana dan prasarana yang harus dimiliki oleh setiap organisasi bisnis, teknologi bermanfaat untuk mempercepat penyelesaian pekerjaan, baik dari segi kualitas maupun kuantitas. Memanfaatkan kemajuan teknologi tidaklah mudah, organisasi juga harus memiliki sumber daya manusia yang terampil dan kompeten, sumber daya manusia merupakan tenaga kerja dalam organisasi yang menggerakkan dan menggunakan teknologi tersebut daam pekerjaan sehari-hari. Organsasi yang memiliki teknologi yang maju akan percuma jika sumber daya manusia yang dimiliki tidak mampu atau tidak dapat menggunakan teknologi tersebut.

Ada banyak faktor yang mempengaruhi kinerja perusahaan seperti: kompetensi, kompensasi, kedisiplinan, kepuasan, kerja, komunikasi, kordinasi, pengalaman, kompetensi, lingkungan kerja, pendidikan, budaya, perusahaan, motivasi. Dalam menghadapi perubahan yang pesat di berbagai bidang tersebut juga perlu melakukan peningkatan kompetensi guna mengikuti tren- tren perubahan yang terjadi untuk diaplikasikan dalam organisasi. Tanpa adanya kompetensi yang didukung oleh sumber daya manusia yang handal, maka organisasi akan mengalami kesulitan untuk dapat bersaing dengan organisasi-organisasi lain.

Karyawan merupakan aset yang paling penting yang harus dimiliki oleh perusahaan dan sangat diperhatikan oleh manajemen. Manusia merupakan elemen yang selalu ada di dalam setiap organisasi. Manusia membuat tujuan, mengadakan inovasi, dan mencapai tujuan organisasi. Sumber daya memicu kreatifitas di setiap organisasi dan tanpa adanya sumber daya manusia yang efektif akan mustahil 
bagi organisasi untuk mencapai tujuannya karena sumber daya manusia dapat membuat sumber daya yang lain berjalan.

Dalam meningkatkan upaya pengembangan karyawan universitas pamulang, instansi dihadapkan dengan hasil kerja pada karyawan yang berkerja. Baiknya hasil kerja karyawan akan meningkatkan kinerja kerja instansi jangka pendek dan jangka panjang.

Minimnya produktifitas kerja karyawan Universitas Pamulang dikarenakan karyawan di instansi ini tidak dapat menyelesaikan pekerjaan dalam jumlah besar, sehingga banyak pekerjaan yang tertunda dan mengakibatkan menurunnya pendapatan instansi. Dan hal ini juga terjadi karena kompetensi yang dimiliki karyawan dari segi pengetahuan dan keterampilan karyawan masih terbilang kurang, sehingga mengganggu jalannya proses pelaksanaan pekerjaaan.

Kompetensi adalah suatu kemampuan yang dilandasi oleh keterampilan dan pengetahuan yang didukung oleh sikap kerja serta penerapannya dalam melaksanakan tugas dan pekerjaan di tempat kerja yang mengacu pada persyaratan kerja yang ditetapkan Sutrisno(2016:203). Kompetensi karyawan dalam suatu instansi berperan penting dalam kemajuan instansi tersebut. Karyawan yang berkompeten sangat diharapkan dalam menunjang aktifitas kerja.

Universitas pamulang juga memiliki peraturan mengenai standar kompetensi dalam merekrut karyawan berdasarkan prinsip profesionalisme sesuai dengan kompetensi, tingkat pengetahuan atau pendidikan serta keahlian dan pengalaman karyawan, yang ditetapkan untuk jabatan tertentu serta syarat obyektif lainnya tanpa membedakan jenis kelamin, suku, agama, ras, atau golongan. Sedangkan Peraturan Menteri Ketenagakerjaan Republik Indonesia Nomor 2Tahun 2016 Tentang Sistem Standar kerja Nasional, dalam Peraturan Menteri ini, yang dimaksud dengan sistem Standardisasi Kompetensi Kerja Nasional adalah tatanan keterkaitan komponen standardisasi kompetensi kerja nasional yang komprehensif dan sinergis dalam rangka meningkatkan kompetensi sumber daya manusia Indonesia, Standar Kompetensi Kerja Nasional Indonesia adalah rumusan kemampuan kerja yang mencakup aspek pengetahuan, keterampilan dan/atau keahlian serta sikap kerja yang relevan dengan pelaksanaan tugas dan syarat jabatan yang ditetapkan sesuai dengan ketentuan peraturan perundang-undangan.

Tingkat pendidikan merupakan faktor penting utama dalam menunjang efektivitas kinerja karyawan. Tingkat pendidikan dapat merubah pola pikir yang lebih baik dari seseorang karyawan yang bekerja dengan dibekali pendidikan yang tinggi dapat dikatakan lebih dapat menyelesaikan tugasnya dengan baik, sehingga kinerja dari perusahaan dapat puas dirasakan. Meliihat ketentuan peraturan internal lembaga dan peraturan perundang-undangan, tingkat pendidikan dan pengetahuan karayawan tidak mengacu pada standar peraturan yang telah ditetapkan, sehingga akan mempengaruhi hasil kerja karyawan.

Kesejahteraan juga merupakan salah satu bentuk kompensasi. Sesuai dengan Peraturan Badan Penyelengaraan Jaminan Sosial No. 5 Tahun 2015 Pasal 2 ayat 1 dan 2, bahwa pemberi kerja selain negara wajib mendaftarkan pekerja yang baru paling lama 30 hari terhitung sejak tanggal pekerja tersebut mulai bekerja. Dan Peraturan UndangUndang Pemerintah Republik Indonesia Nomor 46 Tahun 2015 Pasal 2, 4, 5 dan 6 mengenai Program Jaminan Hari Tua (JHT).

Keputusan Menteri Tenaga Kerja Dan Transmigrasi Republik Indonesia Nomor Kep.102 /Men/VI/2004 pada Pasal 4 ayat 1 Tentang Waktu Kerja Lembur Dan Upah Kerja Lembur mengenai Dalam Keputusan Menteri ini menerangkan bahwa pekerja/buruh melebihi waktu kerja, wajib membayar upah lembur oleh instansi. 
Hasil pengamatan pada tempat penelitian masih adanya kekurangan pada jenis pemberian kompensasi langsung berupa finansial, diantaranya:

Tabel 1

Jenis Pemberian Kompensasi

\begin{tabular}{|c|c|c|}
\hline No & Jenis Motivasi Finansial & Ket \\
\hline 1 & BPJS (Badan Penyelenggaran jasmani kesehatan) & Tidak Ada \\
\hline 2 & Asuransi kesehatan dan JKK (jaminan kecelakan kerja) & Tidak Ada \\
\hline 3 & Pensiun/Pesangon & Tidak Ada \\
\hline 4 & THR & Ada \\
\hline 5 & Upah Lembur & Ada \\
\hline 6 & Insentif Kehadiran & Tidak Ada \\
\hline
\end{tabular}

Sumber : Universitas Pamulang

Tabel diatas menunjukkan bahwa, pemberian kompensasi masih belum memenuhi kesejahteraan karyawan, khususnya pada pemberian pensiun/pesangon. Dimana pemberian uang pensiun/pesangon instansi tidak memberikan kepada karyawan. Dari segi pemberian insentif kehadiran perusahaan tidak ada dan hanya memberikan upah lembur bila karyawan lembur di hari libur kerja ataupun melebihi jam kerja operasional. Hal ini jelas berbeda dengan peraturan perundang-undangan menteri tenaga kerja yang telah dikeluarkan. Dengan belum terpenuhinya pemberian kompensasi ini mengakibatkan karyawan kurang termotivasi dalam meningkatkan kinerjanya.

Demi tercapainya tujuan instansi, karyawan memerlukan motivasi untuk bekerja lebih rajin. Melihat pentingnya karyawan dalam organisasi, maka karyawan diperlukan perhatian lebih serius terhadap tugas yang dikerjakan sehingga tujuan organisasi tercapai. Dengan motivasi kerja yang tinggi, karyawan akan bekerja lebih giat dalam melaksanakan pekerjaannya. Sebaliknya dengan motivasi kerja yang rendah karyawan tidak mempunyai semangat bekerja, mudah menyerah, dan kesulitan dalam menyelesaikan pekerjaannya. Berdasarkan uraian diatas, maka penelitian ini berjudul "Pengaruh Kompensasi, Kompetensi dan motivasi terhadap Kinerja Karyawan Universitas Pamulang”.

\section{B. Rumusan Masalah}

1. Apakah kompensasi berpengaruh terhadap kinerja karyawan pada Universitas Pamulang?

2. Apakah Kompetensi karyawan berpengaruh besar terhadap kinerja karyawan pada Universitas Pamulang?

3. Apakah Motivasi berpengaruh terhadap kinerja karyawan pada Universitas pamulang ?

4. Apakah Kompensasi, Kompetensi dan Motivasi berpengaruh secara simultan terhadap kinerja karyawan pada Universitas Pamulang?

\section{Tujuan Penelitian}

1. Untuk mengetahui pengaruh kompensasi terhadap kinerja karyawan pada Universitas Pamulang?

2. Untuk mengetahui pengaruh Kompetensi terhadap kinerja karyawan pada Universitas Pamulang?

3. Untuk mengetahui pengaruh Motivasi terhadap kinerja karyawan pada pada Universitas Pamulang?

4. Untuk mengetahui pengaruh secara simultan antara kompensasi, Kompetensi, dan Motivasi berpengaruh positif dan signifikan terhadap kinerja karyawan pada Universitas Pamulang? 


\section{METODE PENELITIAN}

\section{Populasi}

Populasi Populasi dalam penelitian ini adalah karyawan yang bekerja pada Universitas Pamulang., sebanyak 120 orang

\section{Sampel}

Teknik sampling yang digunakan adalah teknik sampel jenuh jadi jumlah sampel penelitian sebanyak 120 responden.

\section{Jenis Penelitian}

Jenis penelitian yang dipakai adalah asosiatif, dimana tujuannya adalah untuk mengetahui mencari keterhubungan antara variabel $\mathrm{x}$ dan variabel $\mathrm{y}$

\section{Metode Analisis Data}

Dalam menganalisis data digunakan uji instrumen, uji asumsi klasik, regresi, koefisien determinasi dan uji hipotesis.

\section{HASIL PENELITIAN DAN PEMBAHASAN}

\section{Uji Regresi Linear Berganda}

a. Hasil Uji Regresi Linier Berganda (Uji F/Simultan)

Analisis regresi berganda digunakan untuk mengetahui seberapa besar pengaruh variabel bebas, yaitu: Kompensasi (X1), Kompetensi (X2) dan Motivasi (X3) terhadap Kinerja Karyawan (Y).Berdasarkan hasil analisis uji validasi dan uji reliabilitas sebagaimana diatas, maka dapat disimpulkan bahwa seluruh item instrumen penelitian sudah teruji validitas maupun reliabilitasnya, sehingga telah memenuhi syarat sebagai instrumen yang dapat digunakan untuk mengumpulkan data penelitian.

Uji F digunakan untuk mengetahui pengaruh variabel bebas secara bersamasama (simultan) terhadap variabel terikat.Dalam uji $\mathrm{F}$ dapat dilihat pada tabel ANOVA pada kolom $\mathrm{F}$ untuk melihat pengaruh positif dan kolom significance untuk melihat signifikansi.

Berikut akan peneliti sajikan hasil uji $\mathrm{F}$ antara variabel independen Kompensasi (X1), Kompetensi (X2) dan Motivasi (X3) terhadap variabel dependen Kinerja Karyawan (Y) dengan bantuan program SPSS versi 22.0

Tabel. 2 Uji F

ANOVA $^{\mathrm{a}}$

\begin{tabular}{|l|r|r|r|r|r|}
\hline Model & Sum of Squares & df & Mean Square & F & Sig. \\
\hline Regression & 467,034 & 3 & 155,678 & 4,242 &, $007^{\mathrm{b}}$ \\
Residual & 4367,649 & 119 & 36,703 & & \\
Total & 4834,683 & 122 & & & \\
\hline
\end{tabular}

a. Dependent Variable: KINERJA

b. Predictors: (Constant), KOMPENSASI, KOMPETENSI,MOTIVASI

\section{b. Hasil Uji F (Simultan)}

Dari tabel diatas, diperoleh nilai Fhitung sebesar 4,242> 2,68 atau (Fhitung> Ftabel) sehingga H0 ditolak dan Ha diterima. Artinya terdapat pengaruh yang positif dan signifikan secara simultan (bersama-sama) antara kompensasi,kompetensi danmotivasi terhadap kinerja karyawan.Dan nilai sig. 0,007< dari probabilitas 0,05, maka hasil yang di dapat pengaruh yang signifikan antara Kompensasi(X1), kompetensi (X2) dan Motivasi (X3) secara simultan terhadap Kinerja Karyawan (Y).

Dari penjelasan diatas disimpulkan bahwa hasil ini menunjukan adanya pengaruh antara Kompensasi (X1), Kompetensi (X2) dan Motivasi (X3) terhadap Kinerja Karyawan (Y) secara simultan adalah positif dan signifikan. Dengan demikian 
dapat dikatakan bahwa Hipotesis pada penelitian ini setelah di uji secara simultandapat diterima (Ha. Positif).

c. Analisis Koefisien Determinasi

Tabel. 3. Hasil Pengolahan Data Koefisien Determinasi Kompensasi (X1) terhadap

Kinerja Karyawan (Y)

Model Summary

\begin{tabular}{|l|r|r|r|c|}
\hline Model & \multicolumn{1}{|c|}{$\mathrm{R}$} & R Square & \multicolumn{1}{c|}{$\begin{array}{c}\text { Adjusted R } \\
\text { Square }\end{array}$} & $\begin{array}{c}\text { Std. Error of the } \\
\text { Estimate }\end{array}$ \\
\hline 1 &, $250^{\mathrm{a}}$ &, 062 &, 055 & 6,120 \\
\hline
\end{tabular}

a. Predictors: (Constant), KOMPENSASI

Berdasarkan hasil tabel diatas, dapat diperoleh nilai koefisien $R=0,250$. Artinya korelasi variabel Kompensasi (X1) terhadap variabel Kinerja Karyawan (Y) sebesar 0,250 hal ini dapat di simpulkan bahwa ada hubungan positif sebesar 25,0\% antara variableKompensasi (X1) terhadap Kinerja Karyawan (Y).

Nilai Koefisien Determinasi R Square sebesar 0,062, maka dapat disimpulkan bahwa variabel Kompensasi (X1) berpengaruh terhadap variabel Kinerja Karyawan (Y) sebesar 6,2\% sedangkan sisanya 93,8\% dipengaruhi oleh faktor-faktor lain yang tidak diteliti dalam penelitian ini.

Tabel. 4. Hasil Pengolahan Data Koefisien Kompetensi (X2) terhadap Kinerja Karyawan (Y)

Model Summary

\begin{tabular}{|l|r|r|r|r|}
\hline Model & R & R Square & \multicolumn{1}{|c|}{$\begin{array}{c}\text { Adjusted R } \\
\text { Square }\end{array}$} & $\begin{array}{c}\text { Std. Error of the } \\
\text { Estimate }\end{array}$ \\
\hline 1 &, $195^{\mathrm{a}}$ &, 038 &, 030 & 6,199 \\
\hline
\end{tabular}

a. Predictors: (Constant), KOMPETENSI

Berdasarkan hasil tabel diatas, dapat diperoleh nilai koefisien $R=0,195$. Artinya korelasi variabel Kompetensi(X2) terhadap variabel Kinerja Karyawan (Y) sebesar 0,195 hal ini dapat di simpulkan bahwa ada hubungan positif sebesar 19,5\% antara variable Kompetensi (X2) terhadap Kinerja Karyawan(Y).

Nilai Koefisien Determinasi R Square sebesar 0,038, maka dapat disimpulkan bahwa variabel Kompetensi (X2) berpengaruh terhadap variabel Kinerja Karyawan (Y) sebesar 3,8\% sedangkan sisanya 96,2\% dipengaruhi oleh faktor-faktor lain yang tidak diteliti dalam penelitian ini.

Tabel. 5. Hasil Pengolahan Data Koefisien Determinasi Motivasi (X3) Terhadap

Kinerja Karyawan (Y)

Model Summary

\begin{tabular}{|l|r|r|r|r|}
\hline Model & $\mathrm{R}$ & \multicolumn{1}{|c|}{ R Square } & Adjusted R Square & \multicolumn{1}{c|}{$\begin{array}{c}\text { Std. Error of the } \\
\text { Estimate }\end{array}$} \\
\hline 1 &, $284^{\mathrm{a}}$ &, 081 &, 073 & 5,165 \\
\hline
\end{tabular}

a. Predictors: (Constant), MOTIVASI

Berdasarkan hasil tabel diatas, dapat diperoleh nilai koefisien $R=0,284$. Artinya korelasi variabel Moivasi (X3) terhadap variabel Kinerja Karyawan (Y) sebesar 0,284 hal ini dapat di simpulkan bahwa ada hubungan positif sebesar $28,4 \%$ antara variable Motivasi(X3) terhadap Kinerja Karyawan(Y).

Nilai Koefisien Determinasi R Square sebesar 0,081, maka dapat disimpulkan bahwa variabel Motivasi (X3) berpengaruh terhadap variabel Kinerja Karyawan (Y) sebesar $8,1 \%$ sedangkan sisanya $91,9 \%$ dipengaruhi oleh faktor-faktor lain yang tidak diteliti dalam penelitian ini. 
Tabel. 6. Hasil Pengolahan Data Koefisien Determinasi Variabel Kompensasi (X1), Kompetensi (X2) dan Motivasi (X3) Terhadap Kinerja Karyawan (Y)

Model Summary

\begin{tabular}{|l|r|r|r|c|}
\hline Model & $\mathrm{R}$ & $\mathrm{R}$ Square & $\begin{array}{c}\text { Adjusted R } \\
\text { Square }\end{array}$ & $\begin{array}{c}\text { Std. Error of the } \\
\text { Estimate }\end{array}$ \\
\hline 1 &, $383^{\mathrm{a}}$ &, 147 &, 126 & 5,020 \\
\hline
\end{tabular}

a. Predictors: (Constant), KOMPENSASI, KOMPETENSI, MOTIVASI

Berdasarkan hasil tabel diatas, dapat diperoleh nilai koefisien $R=0,383$. Artinya korelasi variabel Kompensasi (X1), Kompetensi (X2) dan Motivasi (X3) Terhadap Kinerja Karyawan (Y) sebesar 0,383 hal ini dapat di simpulkan bahwa ada hubungan positif sebesar38,3\% antara variabel Kompensasi (X1), Kompetensi (X2) dan Motivasi(X3) Terhadap Kinerja Karyawan(Y).

Berdasarkan hasil tabel diatas, diperoleh nilai koefisien determinasi sebesar 0,147 maka dapat disimpulkan bahwa variabel Kompensasi (X1), Kompetensi (X2) dan Motivasi (X3) Terhadap Kinerja Karyawan(Y) sebesar 14,7\% sedangkan sisanya $85,3 \%$ dipengaruhi oleh faktor-faktor lain yang tidak diteliti dalam penelitian ini.

\section{PEMBAHASAN HASIL PENELITIAN}

\section{Pengaruh Kompensasi (X1) terhadap Kinerja Karyawan (Y).}

Berdasarkan hasil olah data dan uji statistik yang menjelaskan pengaruh Kompensasi (X1) terhadap Kinerja Karyawan (Y), menghasilkan data thitung sebesar 2,839 lebih besar dari ttabel1,657atau $(2,839>1,657)$. Maka dapat disimpulkan terdapat pengaruh yang positif dan signifikan antara Kompensasi (X1) terhadap Kinerja Karyawan(Y) sehingga hipotesis diterima.Sesuai dengan hipotesis yang telah disebutkan Ho ditolak dan Ha diterima.

\section{Pengaruh Kompetensi (X2) terhadap Kinerja Karyawan(Y)}

Berdasarkan hasil olah data dan uji statistik yang menjelaskan pengaruh Kompetensi (X2) terhadap Kinerja Karyawan (Y), menghasilkan data thitung sebesar 2,191 lebih besar dari ttabel 1,656 atau $(2,191>1,656)$. Maka dapat disimpulkan terdapat pengaruh yang positif dan signifikan antara Kompensasi (X2) terhadap Kinerja Karyawan (Y) sehingga hipotesis diterima.Sesuai dengan hipotesis yang telah disebutkan Ho ditolak dan Ha diterima.

\section{Pengaruh Motivasi (X3) terhadap Kinerja Karyawan (Y)}

Berdasarkan hasil olah data dan uji statistik yang menjelaskan pengaruh Motivasi (X3) terhadap Kinerja Karyawan (Y), menghasilkan data thitung sebesar 2,428lebih besar dari ttabel 1,656atau $(2,428>1,656)$. Maka dapat disimpulkan terdapat pengaruh yang positif dan signifikan antara Motivasi(X3) terhadap Kinerja Karyawan(Y) sehingga hipotesis diterima.Sesuai dengan hipotesis yang telah disebutkan Ho ditolak dan Ha diterima.

\section{Pengaruh Kompensasi(X1), Kompetensi (X2) dan Motivasi (X3) Terhadap Kinerja Karyawan (Y)}

Berdasarkan hasil olah data statistik diatas akan menjelaskan pengaruh Kompensasi (X1), Kompetensi (X2) dan Motivasi(X3) secara simultan terhadap Kinerja Karyawan (Y). Dari tabel diatas Nilai Fhitung dalam tabel ANOVA sebesar 4,242 
sedangkan Ftabel sebesar 2,68 maka data tersebut dapat dikatakan terjadi pengaruh simultan yaituFhitung lebih besar dari Ftabel atau $(4,242>2,68)$ sehingga berpengaruh positif. Apabila dihitung dari nilai signifikasi menghasilkan nilai sig. $0,007<0,05$, maka hasil yang di dapat berpengaruh secara signifikan. Dengan demikian sesuai dengan hipotesis yang telah disebutkan Ho ditolak dan Ha diterima

\section{V.PENUTUP}

\section{Kesimpulan}

a. Ada pengaruh positif dan signifikan secara parsial antara Kompensasi (X1) terhadap Kinerja Karyawan (Y) pada Universitas Pamulang. Hal ini ditunjukkan oleh nilai thitung > ttabel $(2,839>1,657)$, dengan nilai signifikansi $(0,005<0,05$.) Maka Ha diterima. Nilai efisien Diterminasi (R2) sebear 0,062, maka dapat disimpulkan bahwa variabel Kompensasi (X1) berpengaruh terhadap variabel Kinerja Karyawan (Y) sebesar 6,2\% tergolong kategori setuju, sedangkan sisanya 93,8\% tergolong kategori tidak setuju dalam penelitian ini.

b. Ada pengaruh positif dan signifikan secara parsial antara Kompetensi (X2) terhadap Kinerja Karyawan (Y) pada Universitas Pamulang. Hal ini ditunjukan oleh nilai thitung > ttabel $(2,191>1,657)$, dengan nilai signifikansi $(0,030<0,05)$. Maka Ha diterima. Nilai koefisien Diterminasi (R2) sebesar 0,038, maka dapat disimpulkan bahwa variabel Kompetensi (X2) berpengaruh terhadap variabel Kinerja Karyawan (Y) sebesar 3,8\% tergolong kategori setuju, sedangkan sisanya 96,2\% tegolong kategori tidak setuju dalam penelitian ini.

c. Ada pengaruh positif dan signifikan secara parsial antara Motivasi terhadap Kinerja Karyawan (Y) pada Universitas Pamulag. Hal ini ditunjukan oleh nilai thitung > ttabel $(2,428>1,657)$, dengan nilai signifikansi $(0,017<0,05)$, Maka Ha diterima. Sedangkan nilai koefisien Diterminasi (R2) sebesar 0,081, maka dapat disimpulkan bahwa variabel Motivasi (X3) berpengaruh terhadap variabel Kinerja Karyawan (Y) sebesar $8,1 \%$ tergolong setuju, sedangkan sisanya 91,9\% tergolong kategori tidak setuju dalam penelitian ini.

d. Ada pengaruh positif dan signifikan secara simultan antara Kompensasi (X1), Kompetensi (X2) dan Motivasi (X3) terhadap kinerja Karyawan (Y) pada Universitas Pamulang. Hal ini ditunjukan oleh nilai Fhitung > Ftabel, dengan nilai signifikansi 4,242 < 2,68). Maka Ha diterima. Sedangkan nilai koefisien Diterminasi (R2) sebesar 0,147 menunjukkan bahwa Kinerja Karyawan (Y) dipengaruhi oleh Kompensasi (X1), Kompetensi (X2) dan Motivasi (X3) sebesar 14,7\% tergolong kategori setuju, sedangkan sisanya $85,3 \%$ tergolong kategori setuju dalam penelitian ini.

\section{Saran}

a. Agar perusahaan/ instansi memberikan kompensasi yang sesuai dengan kompetensi yang dimiliki karyawan agar dapat meningkatkan kinerja karyawan.

b. Karyawan harus ditempatkan pada bidang yang sesuai dengan kompetensi yang dimilikinya

c. Pimpinan harus bisa memberikan motivasi kepada karyawan agar dapat meningkatkan kinerja.

d. Dengan meningkatnya kinerja karyawan akan memberikan keuntungan bagi perusahaan.

e. Harus ada penelitian lebih lanjut menggunakan variable bebas yang lain dan menambah sampel seperti pimpinan agar memperoleh hasil yang lebih real. 


\section{DAFTAR PUSTAKA}

Ahmadi. 2004. Sosiologi Pendidikan. Jakarta: PT Rineka Cipta.

Akbar, I. R. (2018). Analisis Kebijakan Kepala Sekolah Dalam Upaya Meningkatkan Kompetensi Guru (Study Kasus Pada SMK Muhammadiyah Parung). Tesis. Universitas Pamulang (2020). Pengaruh Kompensasi Dan Etos Kerja Terhadap Komitmen Organisasi Pada Pt. Central Buana Mandiri. Value: Jurnal Manajemen dan Akuntansi, 15(1), 73-80.

Anni, Catharina Tri. 2006. Psikologi Belajar. Semarang: Universitas Negeri Semarang. Appley, Lawrence A. dan Lee, Oey Liang. 2010. Pengantar Manajemen. Jakarta: Salemba Arifin, Zainal. 2009. Evaluasi Pembelajaran. Bandung: PT. Remaja Rosdakarya.

Daft, Richard L. 2006. Management (Manajemen). Jakarta: Salemba Empat.

Dalyono. 2009. Psikologi Pendidikan. Jakarta: Rineka Cipta.

Departemen Pendidikan Nasional. 2008. Kamus Besar Bahasa Indonesia Pusat Bahasa. Edisi Keempat. Jakarta: PT. Gramedia Pustaka Utama.

Dessler, Gary. 2011. Manajemen Sumber Daya manusia. Jilid 1. Edisi 10. Jakarta: Indeks Djamarah, Syaiful Bakri. 2008. Psikologi Belajar. Jakarta : PT. Rineka Cipta.

Engkoswara. 2010. Administrasi Pendidikan. Bandung: Alfabeta.

Ghozali, Imam. 2011. Aplikasi Analisis Multivariate dengan Program IBM SPSS 19. Semarang: Badan Penerbit Universitas Diponegoro.

Ghozali. 2005. Analisis Multivariant dengan Program SPSS. Semarang: UNDIP

Griffin, R.W.2004. Manajemen. Edisi 7. Jakarta: Erlangga.

Hamalik, Oemar. 2007. Proses Belajar Mengajar. Cetakan II. Bandung: PT. Bumi Aksara.

Handoko, Hani, Reksohadiprojo. 2008. Manajemen Personalia dan Sumber Daya Manusia. Yogyakarta: BPFE.

Hasibuan, Malayu S. P. 2008. "Manajemen Sumber Daya Manusia”. Jakarta: PT. Bumi Aksara

Hidayat, D., Prabowo, B., \& Anwar, S. (2020). Organizational Leadership and Conflict in Human Resource Management Review. Solid State Technology, 63(6), 1372-1381.

Jihad, Asep dan Haris, Abdul. 2009. Evaluasi Pembelajaran. Cetakan III. Yogyakarta: Multi Pressindo.

Kanto, Kulase. 2015. The Influence of Motivation and Work Satisfaction toward Performance of Senior High School Guidance and Counseling Teachers in South Sulawesi. International Journal of Advanced Research Volume 3 Issue 2 (hlm. 386401).

Khoiri, A. (2017). Analisis Kemampuan Berfikir Kritis Siswa Menggunakan Teams Assisted Individualization (Pembelajaran Sains Materi Gerak). SEJ (Science Education Journal), 1(2), 52-63.

Kurnianing, Aulia Putri. 2012. Hubungan Lingkungan Belajar di Institusi Pendidikan dan Motivasi Belajar dengan Prestasi Belajar Mahaiswa Program Studi DIII Kebidanan STIKES ‘Aisyiyah Surakarta. Gaster Volume 9 No.2.

Maja, Ibnu. 2013. Pengaruh Motivasi, Metode Pembelajaran dan Disiplin Belajar terhadap Prestasi Belajar Matematika Teknik di Politeknik Negeri Sriwijaya. Jurnal Orasi Bisnis Edisi ke-IX ISSN: 2085-1375

Malayu, S.P Hasibuan. 2000. Manajemen Sumber Daya Manusia. Bandung: PT. Bumi Aksara.

Malhotra, Naresh, K. 2010. Marketing Reseacrh, An Applied Pearson Education

Nashar, Drs. 2004. Peranan Motivasi dan Kemampuan awal dalam kegiatan Pembelajaran. Jakarta: Delia Press. 
Pidarta, Made. 2009. Landasan Kependidikan. Cetakan Kedua. Jakarta: Rineka Cipta. Rafiqah, Mar'atur. 2012. Pengaruh Motivasi Belajar terhadap Prestasi Belajar pada SiswaSiswi kelas XI SMA Negeri 2 Metro Tahun Pelajaran 2012-2013. Jurnal Penelitian Ilmiah.

Riduwan, M.B.A. 2014. Metode dan Teknik Menyusun Tesis. Bandung: Alfabeta.

Rivai, Veithzal. 2004. Manajemen Sumber Daya Manusia Untuk Perusahaan. Jakarta: PT. Raja Grafindo Persada.

Santoso, Singgih. 2011. SPSS Statistik Parametik. Cetakan Kedua. Jakarta: PT. Efek Media.

Sardiman. 2009. Interaksi dan Motivasi Belajar. Jakarta: PT. Raja Grafindo Persada.

Sari, Ika Rizkhi Purnama. 2013. Analisis Pengaruh Proses Belajar Mengajar, Motivasi Belajar dan Lingkungan Belajar Kampus terhadap Prestasi Belajar Mahasiswa. Skripsi. Program Sarjana Fakultas Ekonomika dan Bisnis Universitas Diponegoro.

Schermerhorn, J.R. 2003. Manajemen. Buku I. Edisi Bahasa Indonesia, Management 5e. Yogyakarta: Andi.

Siregar, Syofian. 2016. Satatistik Parametrik Untuk Penelitian Kuantitatif. Jakarta: Bumi Aksara.

Slameto. 2003. Belajar dan Faktor-Faktor yang Mempengaruhinya.. PT Rineka Cipta, Jakarta.

Sugihartono, dkk. 2007. Psikologi Pendidikan. Yogyakarta: UNY Press.

Sugiyono. 2006. MetodePenelitian Kuantitatif, Kualitatif dan R\&D. Bandung: Alfabeta.

Sujarweni, V Wiratna. 2014. Metodologi Penelitian. Yogyakarta: Pustaka Baru Press.

Sunarsi, D. (2016). Hubungan Pengendalian Diri dengan Prestasi Belajar. Penelitian. Fakultas Ekonomi Universitas Pamulang. (2016, October). Pengaruh Minat, Motivasi Dan Kecerdasan Kognitif Terhadap Prestasi Belajar (Studi Kasus Pada Mahasiswa Program Studi S-1 Manajemen. Fakultas Ekonomi. Universitas Pamulang. Thn. Akademik 2015-2016). In Proceedings (Vol. 1, No. 1).

(2017). Pengaruh Disiplin, Motivasi, Dan Kompetensi Terhadap Prestasi Belajar (Studi Kasus Pada Mahasiswa Universitas Pamulang, Tangerang Selatan Tahun Akademik 2016-2017). Jurnal Mandiri: Ilmu Pengetahuan, Seni, Dan Teknologi, 1(2), 207-226.

Suprijono, Agus. 2009. Cooperative Learning Teori dan Aplikasi PAIKEM. Yogyakarta: Pustaka Pelajar.

Suryabrata, Sumadi. 2011. Psikologi Pendidikan. Jakarta: PT. Raja Grafindo Persada.

Sutrisno, S., \& Sunarsi, D. (2019). The Effect of Work Motivation and Discipline on Employee Productivity at PT. Anugerah Agung in Jakarta. Jurnal Ad'ministrare, 6(2), 187-196.

Syah, Muhibbin. 2008. Psikologi Pendidikan dengan Pendekatan Baru. Bandung: PT. Remaja Rosdakarya.

Terry, George R. 2010. Teori Manajemen. Jakarta: Bina Aksara.

Tu'u, Tulus. 2004. Peran Disiplin Pada Perilaku dan Prestasi Siswa. Jakarta: PT. Gramedia Widiasarana. 